\title{
SIMPLIFIED SEISMIC VULNERABILITY ASSESSMENT OF MEDIEVAL MASONRY CHURCHES
}

\author{
V. CORLITO ${ }^{1}$, M. ZIZI ${ }^{1}$ AND G. DE MATTEIS ${ }^{2 *}$ \\ ${ }^{1}$ Department of Architecture and Industrial Design (DADI) \\ University of Campania "Luigi Vanvitelli" \\ San Lorenzo Abbey, 81030 Aversa, Italy \\ email: \{valentina.corlito, mattia.zizi\}@unicampania.it \\ ${ }^{2}$ Department of Architecture and Industrial Design (DADI) \\ University of Campania "Luigi Vanvitelli" \\ San Lorenzo Abbey, 81030 Aversa, Italy \\ e-mail: gianfranco.dematteis@unicampania.it, (*corresponding author)
}

Keywords: Masonry Churches, Typological Characterization, Seismic Vulnerability Assessment, FEM Model, Seismic damage

\begin{abstract}
The meaningful seismic events occurred in Italy in the last decades showed the high vulnerability of monumental buildings and in particular of churches. In order to preserve such a precious heritage, operations aimed at the seismic risk mitigation based on the definition of suitable vulnerability assessment procedure are necessary. The high hazard of the Italian Peninsula and the huge amount of ecclesiastic buildings located in the exposed territories, stress the need to face the problem with innovative large-scale approaches. In this study, an architectural-engineering integrated procedure for the seismic assessment of existing masonry churches at a regional scale is proposed. Based on accurate historical investigation of typical Abruzzi churches, a typological characterization has been established, aimed at recognizing the common geometrical and constructive features of two types of medieval churches widespread in this area. Then, a numerical analysis has been carried out. In particular, by assuming simplified modelling hypotheses, two FE models representative of significant real cases have been implemented in Abaqus. By the elastic analyses, the main collapse mechanisms and the corresponding activation seismic accelerations have been determined. The obtained outcomes show an acceptable correspondence with the actual seismic damage revealed on similar churches in the aftermath of last seismic events, corroborating the reliability of the adopted integrated approach.
\end{abstract}

\section{INTRODUCTION}

Due to the geographical location and the complex tectonic system, the Abruzzi is one of the most earthquake-prone area in Italy. The dramatic impact of the last seismic events (i.e. L'Aquila 2009 and Central Italy 2016-17) highlighted the strong exposure of such area and the high fragility of the relevant architectural heritage, with particular reference to the historical masonry churches.

The above remarks emphasise the necessity to plan effective strategies at territorial scale 
for a preventive framework, based on the definition of suitable large-scale vulnerability assessment methodologies, aimed at estimating the hypothetical consequences of a seismic event $[1-4]$. In this perspective, a seismic risk assessment should require a multidisciplinary approach taking into consideration not only the immediate structural issue, but also the influence of the architectural and geometrical features of the investigated constructions on their seismic behaviour $[5,6]$.

In this paper, a brief overview of the historical and typological characterization of the Abruzzi ecclesiastic architecture is presented, focusing on two of the most common types of medieval churches, namely the Benedictine and the Franciscan typologies. Then, a numerical investigation is carried out by assuming simplified modelling hypotheses concerning the thickness of the structural elements, the roofing systems and the mechanical properties of the materials. Finally, a comparison between the outcomes of the simplified elastic analyses and the actual damage scenarios observed in the aftermath of the L'Aquila (2009) and the Central Italy (2016-17) earthquakes is presented, allowing to prove the reliability of the proposed approach.

\section{RELIGIOUS ARCHITECTURE IN ABRUZZI}

\subsection{Historical basis}

The historical investigation of the religious architecture of Abruzzi starts from the Middle

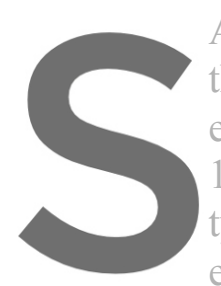
Ages, with the constructi the $11^{\text {th }}$ century [7]. Among oti erected in 1080 in Serra 1). Different Benedictint typologically linked existence of a Benedictine structural elements. Among these, the following elements are recognizable: i) the use of a

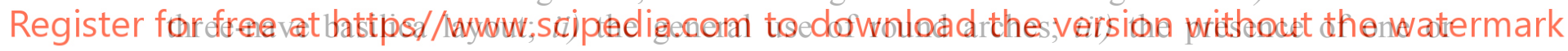
(more frequently) three external semi-circular apses; $i v$ ) the absence of vaults, except for the presbytery; $v$ ) the use of a simple salient shape for the façade.

The Benedictine abbeys almost never received the stylistic and structural innovations proposed by the French Gothic architecture, which were instead introduced in Abruzzi by the Cistercian Order. Few examples of Cistercian churches can be found in the region, which appear significantly modified or in ruins; nonetheless, the influence of such an Order on the religious architecture of the area was certainly decisive from a structural point of view, since it involved the widespread use of pointed arches, cross vaults and external buttresses in the churches.

The Middle Ages were also very important for the typological definition of the Franciscan Architecture. The churches built in Abruzzi between the $13^{\text {th }}$ and $14^{\text {th }}$ centuries according to this Order were generally composed of a single nave covered with wooden trusses and with a single vaulted apse (Figure 2a). Less commonly, and in particular in the area of Avezzano (Aq), the single nave was defined by the juxtaposition of three squared cells, covered by cross vaults. In all cases, the façades were typically characterized by a simple flat shape.

The Franciscan type experienced a wide diffusion in Abruzzi, so extensively to represent a valid alternative to the prevalent Benedictine model. Most of the Franciscan buildings were 


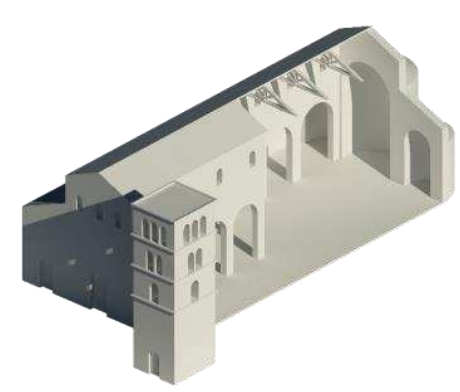

(a)

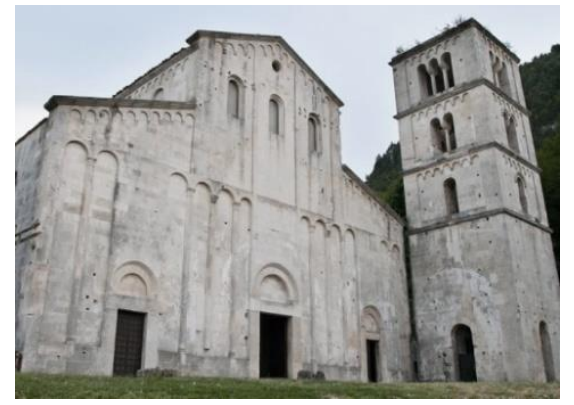

(b)

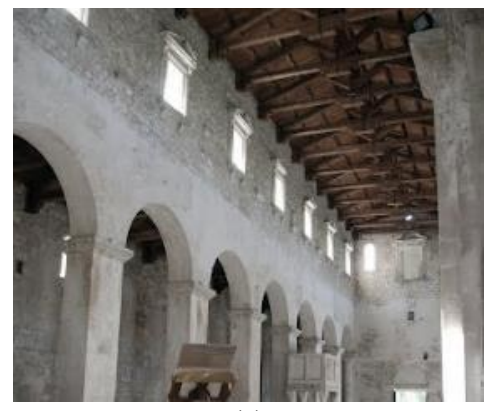

(c)

Figure 1: S. Liberatore alla Majella church in Serramonacesca (Pe): (a) model; (b) external and (c) internal photographic survey.
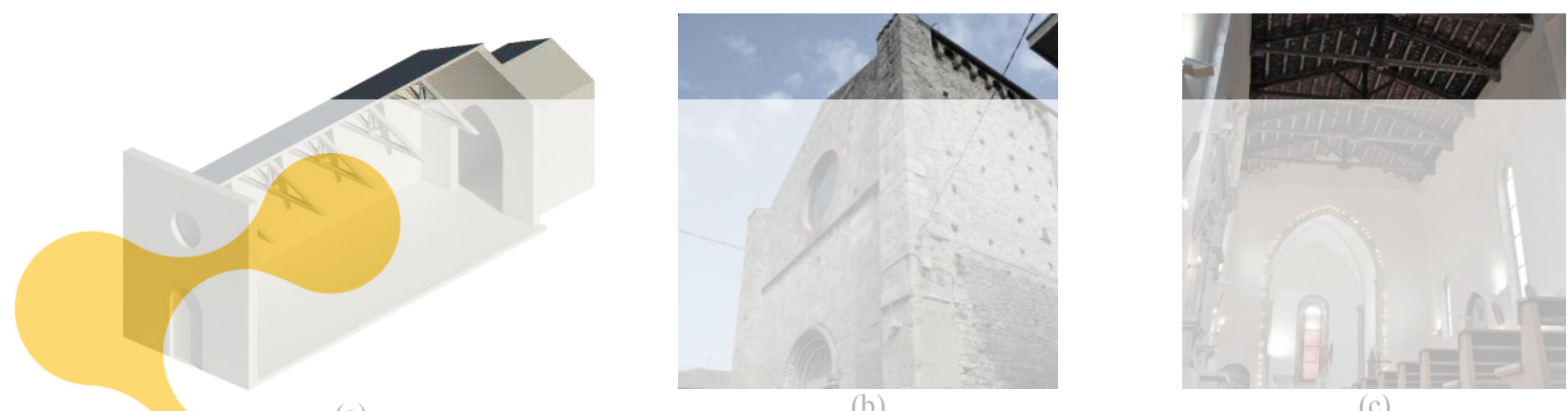

(a) (b)

(c)

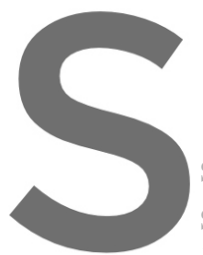

Figure 2: Franciscan

ibjected to significant

still clearly visible in the

interiors in the $17^{\text {th }}$ and $18^{\text {th }}$ cen
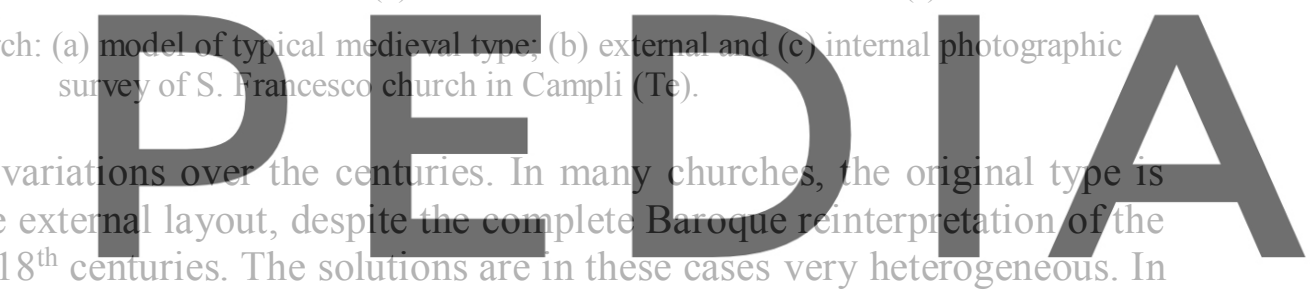

some modified Franciscan churches, the reinterpretation of the internal space was carried out

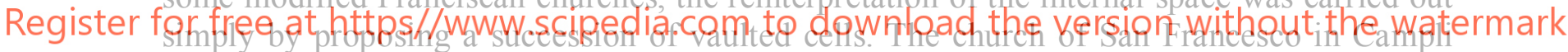

(Te) is the only case of not-modified Franciscan structure in the Abruzzi territory (Figure 2c).

In this specific case, the gabied facade represents a variation from the more common flat shape (Figure 2b).

The foundation of the city of L'Aquila in the $13^{\text {th }}$ century represents another fundamental step in the study of the medieval religious architecture of Abruzzi, given its influence in defining the main features of the religious architecture of the whole region [8]. Even if none of the original churches preserved its first structure, the presence of common features allows to identify basic medieval types, mainly characterized by a one-nave or basilica layout and by the common use of structural elements typical of the Cistercian-Franciscan Gothic and Romanesque style.

In Figure 3 the distribution of the most common types of medieval churches, namely the Benedictine [BN] and the Franciscan [FR] ones, in the Dioceses of Abruzzi is shown.

\subsection{Geometric characterization}

It is well known that the architecture of specific religious Orders is generally characterized by precise design rules and geometric proportions related to functional, cultural and symbolic 


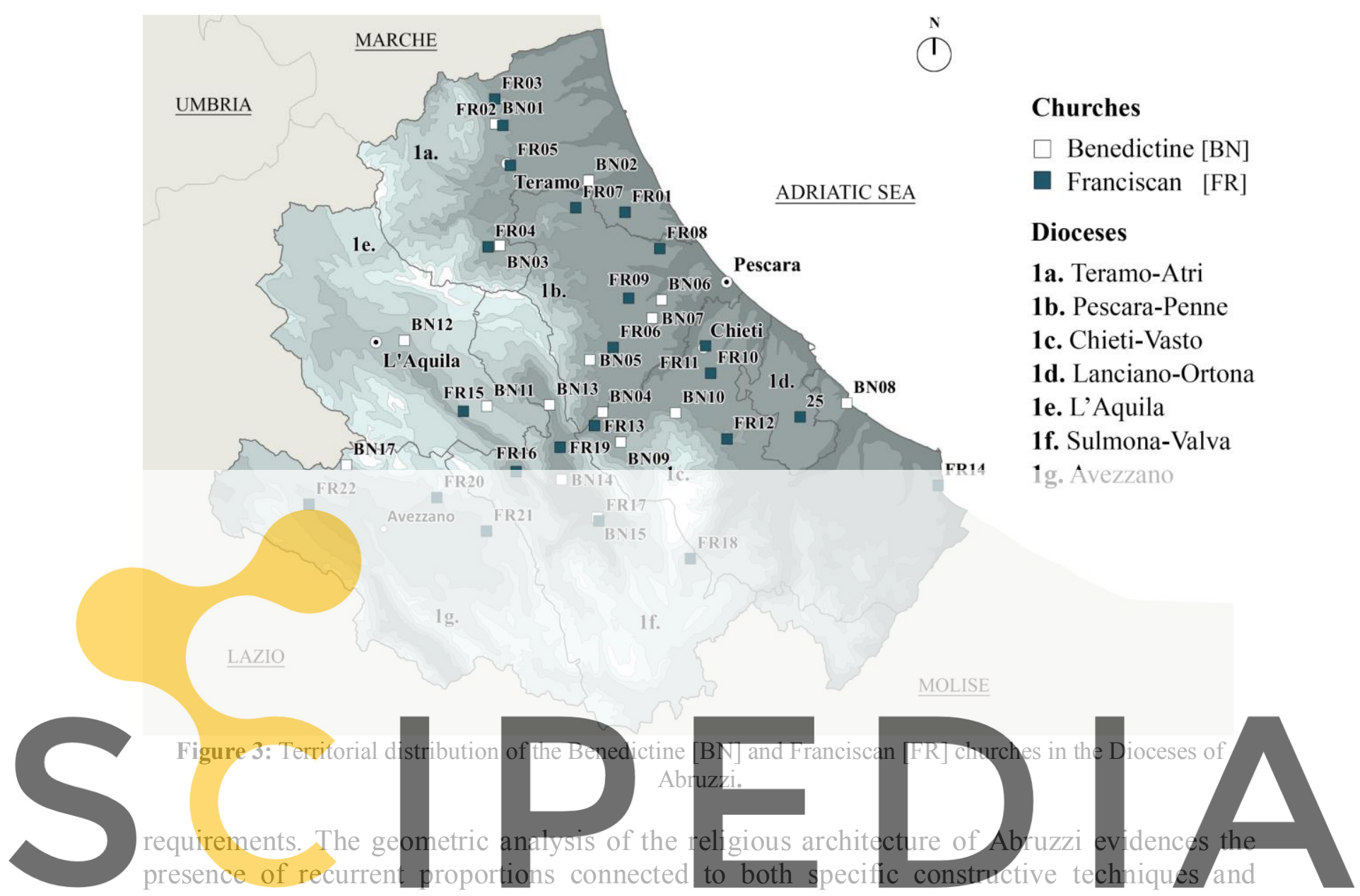

design rules. These proportional devices are fundamental in defining the aesthetics of

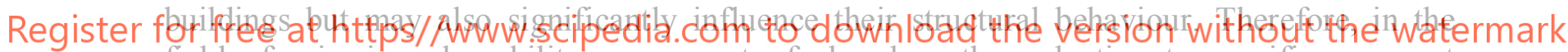

field of seismic vulnerability assessment of churches, the reduction to specific recurrent geometric models may provide a valid simplified tool for the large-scale study of these historical buildings.

In the Benedictine monastic churches of Abruzzi different common elements related to the Benedictine school of San Liberatore can be recognized [7]. The used unit of measurement is the cubit of Roman derivation. The basilica layout is defined by the combination of ad quadratum (i.e. squared) modules, which can also be recognized in the development of the façade and in the definition of the interiors. The plan is characterized by the juxtaposition of four large squares for the central nave and eight smaller ones for each aisle. The central nave width-total width ratio is equal to 0.43 , meaning that the span of the central nave is almost twice the width of the aisles. The design rules used in the church of San Liberatore were also transposed in all the Benedictine churches built in Abruzzi in the successive years. Despite the clear reference to the San Liberatore model, in these buildings tangible dimensional and proportional differences can be identified (Figure 4).

As far as the Franciscan architecture is concerned, relevant churches reached generally a maximum length of about 60 meters, including the apse. The churches built according to this model were characterized by a one-nave layout defined by the combination of three ad 
quadratum modules, completed by an external quadrangular apse. The width-length ratio of the nave was generally 1:3 (0.33). The church of San Francesco in Campli (Te) is one of the few examples of Franciscan churches of Abruzzi; it is very close to the typical features and proportions of the architecture of this Order. In Figure 5 the plan-height variations of some Franciscan buildings identified in the Abruzzi territory are shown.
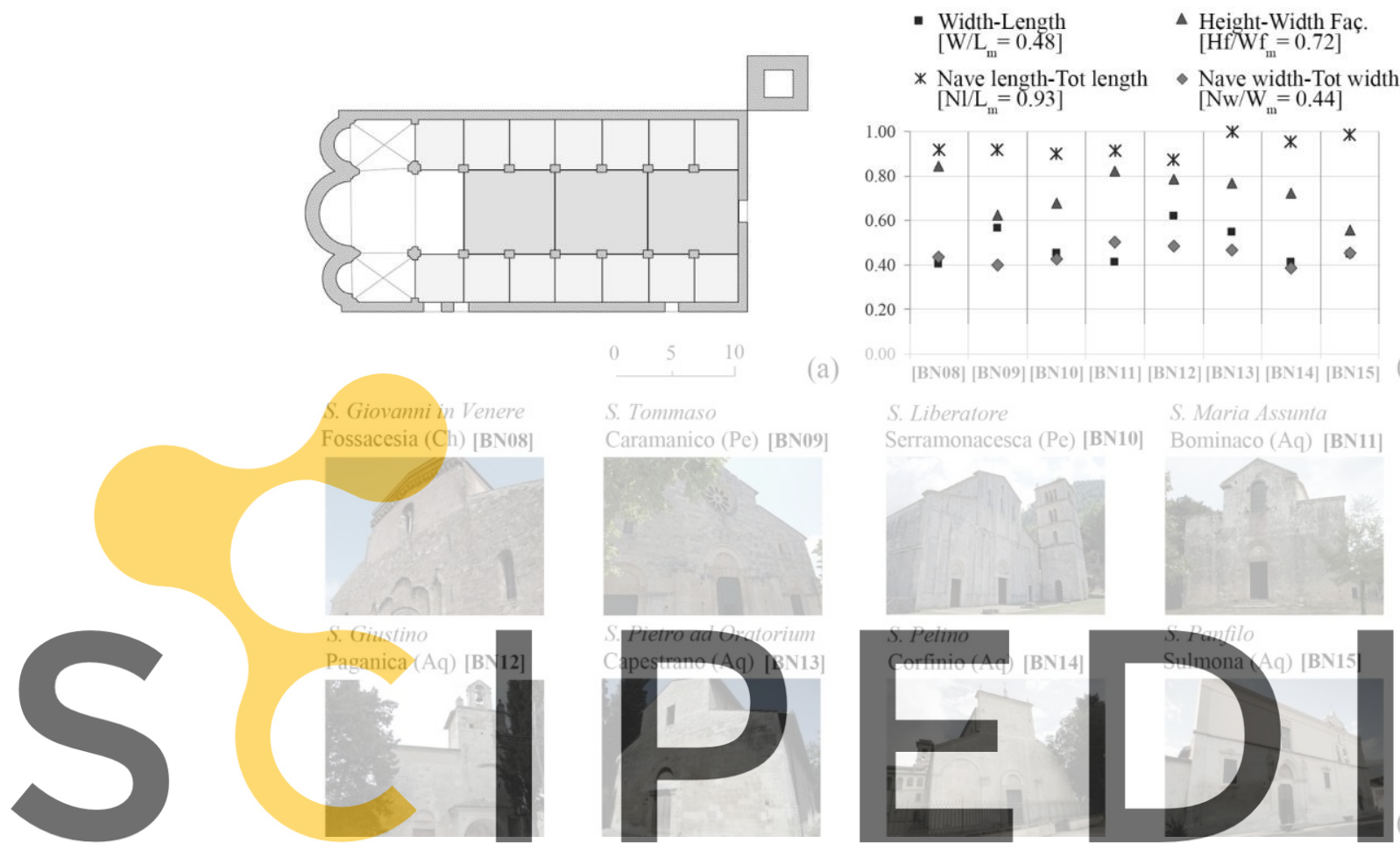

(a)
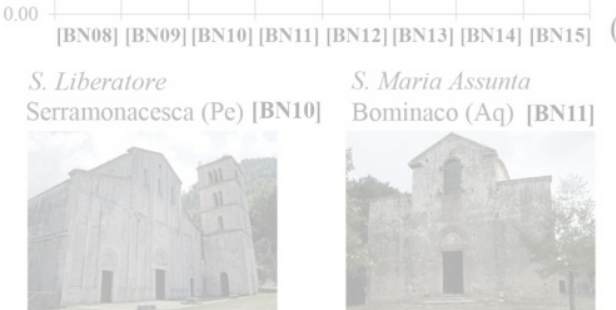

S. Maria Assunta
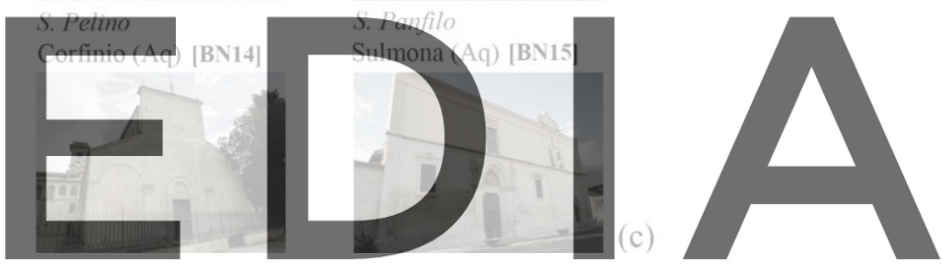

Figure 4: Benedictine churches [BN]: (a) geometric proportions of the San Liberatore church; (b) plan-height

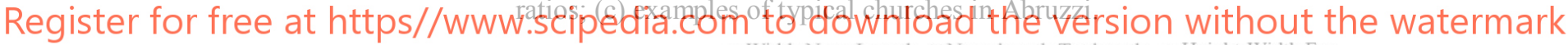
" Width-Nave Length $*$ Nave length-Tot length $\Delta$ Height-Width Fac, $\left[\mathrm{W} / \mathrm{L}_{\mathrm{Nm}}=0.38\right] \quad[\mathrm{NI} / \mathrm{L}=0.79] \quad\left[\mathrm{Hf} / \mathrm{Wf}_{\mathrm{m}}=1.35\right]$

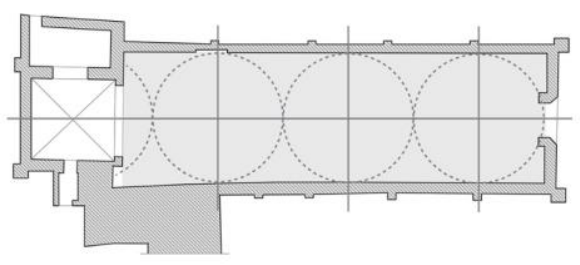

(a)

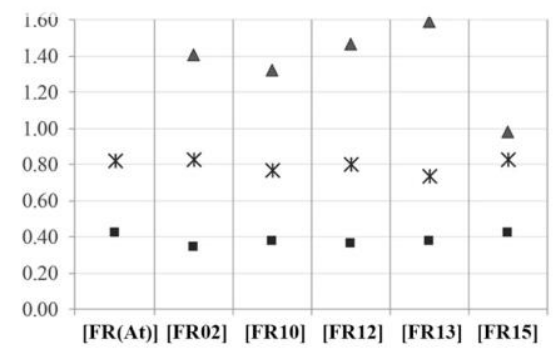

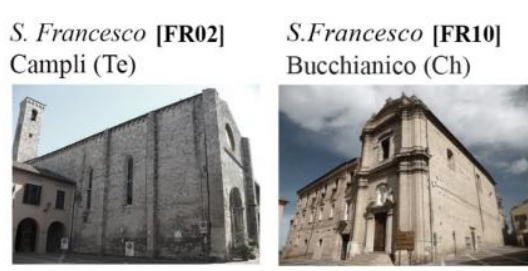

${ }^{*}[\mathbf{F R}(\mathbf{A t})]=$ Modified $(\mathrm{XVIII}$ cent. $)$

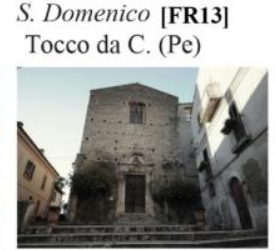

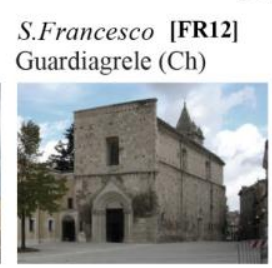

Francesco [FR1 Fontecchio (Aq)

Figure 5: Franciscan churches [FR]: (a) geometric proportions of the San Francesco church in Campli (Te); (b) plan-height ratios; (c) examples of typical churches in Abruzzi. 
It is worth noting that the proportions led by the religious Orders for ecclesiastic buildings are not recognizable when larger populations of churches are examined; in fact, the historical events and the possible marginality of some cultural contexts generally implied the absence of specific typological references, favouring the use of varying geometrical rules.

\subsection{Material and construction techniques}

The widespread presence of stones in the inner part of Abruzzi justifies the large use of this material for historical masonry constructions [9, 10]. In the Medieval churches, namely Romanesque and Gothic churches or, more generally, religious structures built by the Orders from the $11^{\text {th }}$ to the $14^{\text {th }}$ century, the quality of masonry is typically good, because of a well refined arrangement characterised by a regular pattern of stones.

A significant example of the typical constructional features of Benedictine churches is represented by the masonry pattern detected in the church of S. Pietro ad Oratorium in Capestrano (Figure 6).

In some cases, and in particular for the Franciscan churches, the lateral walls are made up of poorer materials arranged with a less regular pattern. This solution was linked to different factors, including the need to use in-situ materials and the frequent post-seismic reconstructions.

In the Adriatic part of Abruzzi, a wider variation of the building materials connected to the various local outcrops can be identified. Differently from the inner part of the Region, the predominance of clays in the coastah soils led to a frequent use of fire clay bnicks in every
parts of the ecclesiastical buildings.
Such aspects put into clear evidenge how the use of materials in historical constructions
can be influenced by the nature of the lithological outcrops of the sites, so that it is possible to
identify variations in the used raw materials, although obvious difference in the adopted
construction techniques are notalways recognizablc.

Register for free at https//www.scipedia.com to download the version without the watermark
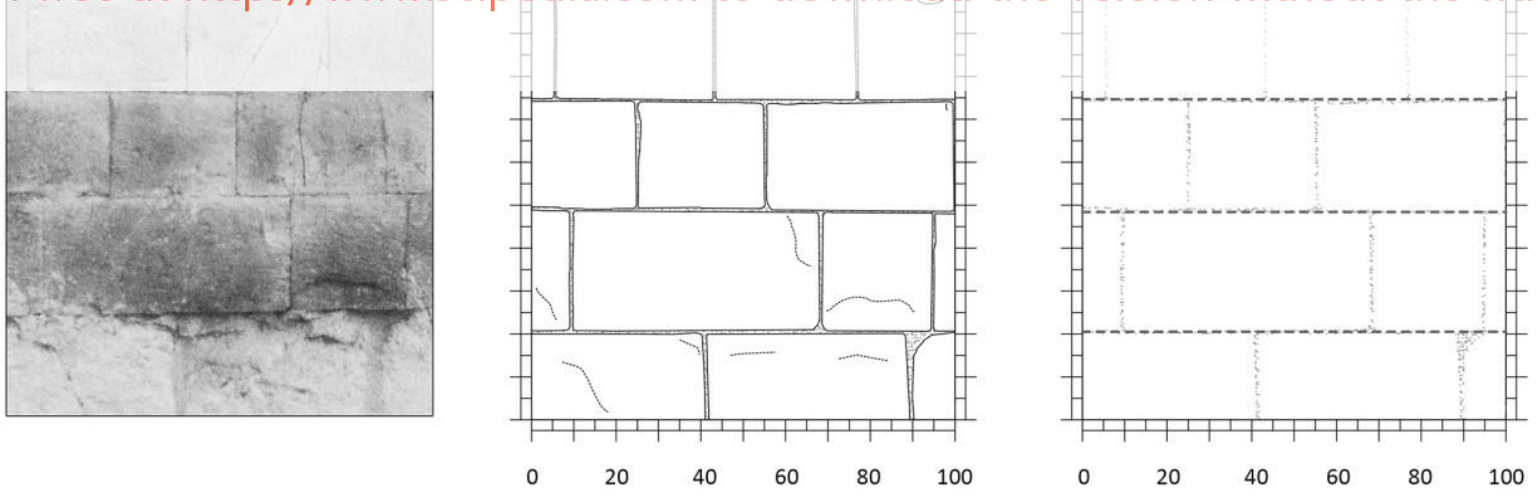

Figure 6: Masonry pattern observed in the church of S. Pietro ad Oratorium church in Capestrano (Aq).

\section{SEISMIC VULNERABILITY ANALYSIS}

\subsection{General}

Based on the typological characterization proposed in the previous section, a numerical 
study has been carried out. In particular, the seismic response of the two typical examples of Benedictine and Franciscan churches have been investigated by means of simplified FEM Models. The adopted models and the assumptions underlying their implementations, as well as the obtained outcomes, are provided in the following.

\subsection{Implemented numerical model and performed analysis}

The seismic response assessment of a masonry church by means of FEM Model is generally a complex issue, which is highly affected by the global and local behaviour of the structural elements [11-13]. Since the present study aims at determining the main structural vulnerabilities of the detected architectural types, simplified and common assumptions have been made in the implemented numerical models. In particular, the linear analyses have been carried out by modelling the masonry material as a continuum, adopting a macro-modelling technique [14] and assuming a conventional engineering level of the material strength (referable to a limestone masonry) equal to $0.3 \mathrm{MPa}$ and $5 \mathrm{MPa}$ in tension and compression, respectively [15]. A material density $\rho=2000 \mathrm{Kg} / \mathrm{m}^{3}$, an Elastic Modulus E=2100 MPa and a Poisson's coefficient $v=0.35$ have been adopted. Hence, by assuming seismic forces proportional to the mass distribution, the first collapse mechanisms and the corresponding horizontal acceleration levels have been determined by using simple models implemented in Abaqus, considering solid elements with 8 and 6 nodes (i.e. C3D8R and C3D6, respectively) for masonry walls.

\section{To this purpose,}

[BN10] and San Fran

flat shape has been cons

masonry walls has been

Franciscan church a

way, the study has bect
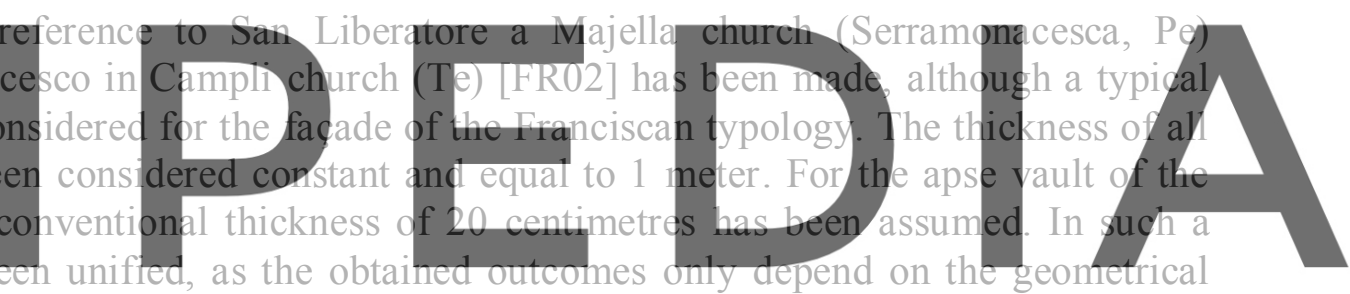

configurations typical of each religious Order

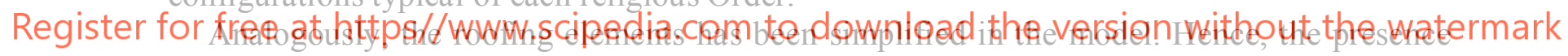

of typical timber trusses or simple beams with regular spans of 4 meters and a uniform weight of $2 \mathrm{kN} / \mathrm{m}^{2}$ has been assumed. The roof loads have been distributed on the lateral $(80 \%)$ and transversal $(20 \%)$ walls, while the stiffening contribution has been accounted for by means of axial springs. In particular, based on a preliminary analytical evaluation, axial springs placed in the central nave between the node on the top of lateral walls with a stiffness of $1 \mathrm{kN} / \mathrm{mm}$ have been hypothesized. Similarly, the stiffening contribution of the roofing system of the lateral naves of the Benedictine church has been simulated by using springs with an axial stiffness of $0.1 \mathrm{kN} / \mathrm{m}$.

Since the medieval typologies are commonly characterized by good constructional quality, a perfect continuity between adjacent masonry walls has been considered in the adopted meshes to define the connection between orthogonal elements.

Hence, the analyses have been developed in two steps: in the first one, vertical loads have been applied (roofing loads and gravity loads), while in the second one, a uniform horizontal acceleration have been introduced. Since the geometric models are characterized by symmetry about the longitudinal axis, three analyses for each model have been carried out, one for the transversal direction $(+\mathrm{x})$ and two for the longitudinal directions $( \pm \mathrm{y})$. 
Some pictures of the implemented FEM models for both [BN] and [FR] church types are provided in Figure 7.

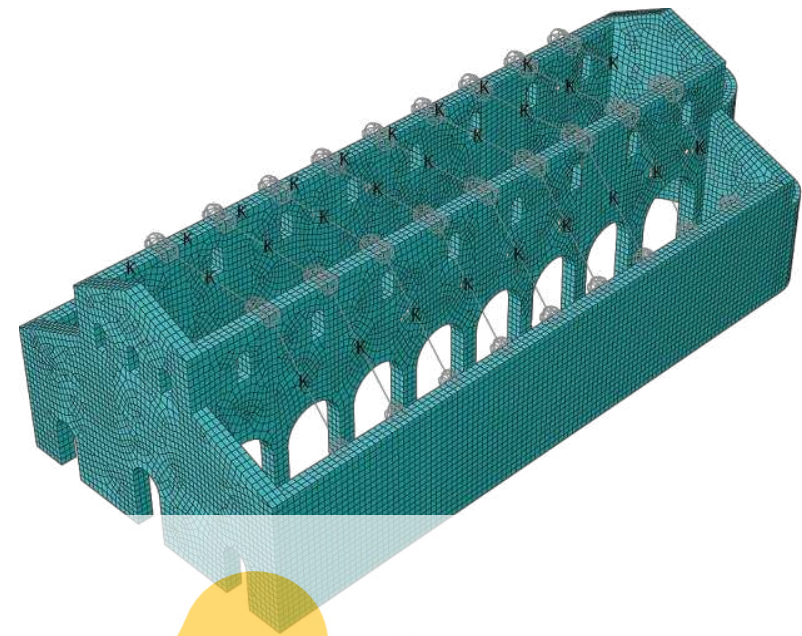

(a)

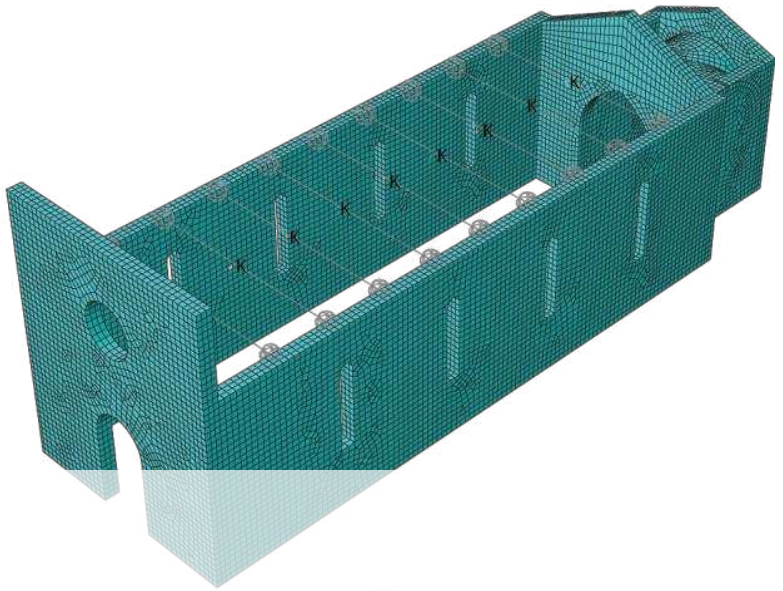

(b)

Figure 7: Implemented FEM Models: (a) [BN] and (b) [FR] church types.

\subsection{The obtained results}

The main outputs a

the corresponding accel

quality and topography ty

been disregarded in these analyses, the

in absolute terms, but

behaviour of the two analysed typologies. Tl

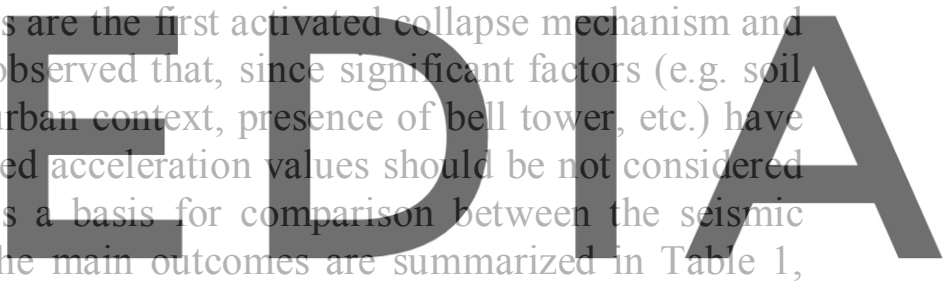

where the collapse mechanisms and the corresponding accelerations of activation are

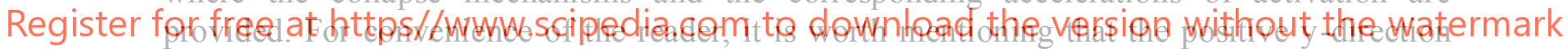
corresponds to accelerations applied in the frontal direction of the façades. In Figure 8 and Figure 9, the stress pattern obtained in each analysis at the acceleration corresponding to the mechanism activation are provided for $[\mathrm{BN}]$ and $[\mathrm{FR}]$ types, respectively.

Table 1: Main outcomes of the numerical study.

\begin{tabular}{|c|c|c|c|}
\hline $\begin{array}{l}\text { Church } \\
\text { typology }\end{array}$ & $\begin{array}{l}\text { Seismic } \\
\text { direction }\end{array}$ & Collapse mechanism & $\begin{array}{c}\text { Activation } \\
\text { acceleration }\end{array}$ \\
\hline \multirow{3}{*}{$\begin{array}{l}\text { Benedictine } \\
\text { [BN10] }\end{array}$} & $+\mathrm{x}$ & $\begin{array}{l}\text { - In-plane cracking of the façade } \\
\text { - Detachment of the connection between longitudinal } \\
\text { walls and façade }\end{array}$ & $0.06 \mathrm{~g}$ \\
\hline & $+\mathrm{y}$ & - Failure of the colonnades (apse side) & $0.16 \mathrm{~g}$ \\
\hline & $-\mathrm{y}$ & - In-plane failure of the longitudinal arch (apse side) & $0.10 \mathrm{~g}$ \\
\hline \multirow{3}{*}{$\begin{array}{c}\text { Franciscan } \\
\text { [FR02] }\end{array}$} & $+\mathrm{x}$ & - Cracking of the apse vault & $0.24 \mathrm{~g}$ \\
\hline & $+\mathrm{y}$ & - Overturning of the top of the façade & $0.14 \mathrm{~g}$ \\
\hline & $-\mathrm{y}$ & - Overturning of the top of the façade & $0.06 \mathrm{~g}$ \\
\hline
\end{tabular}




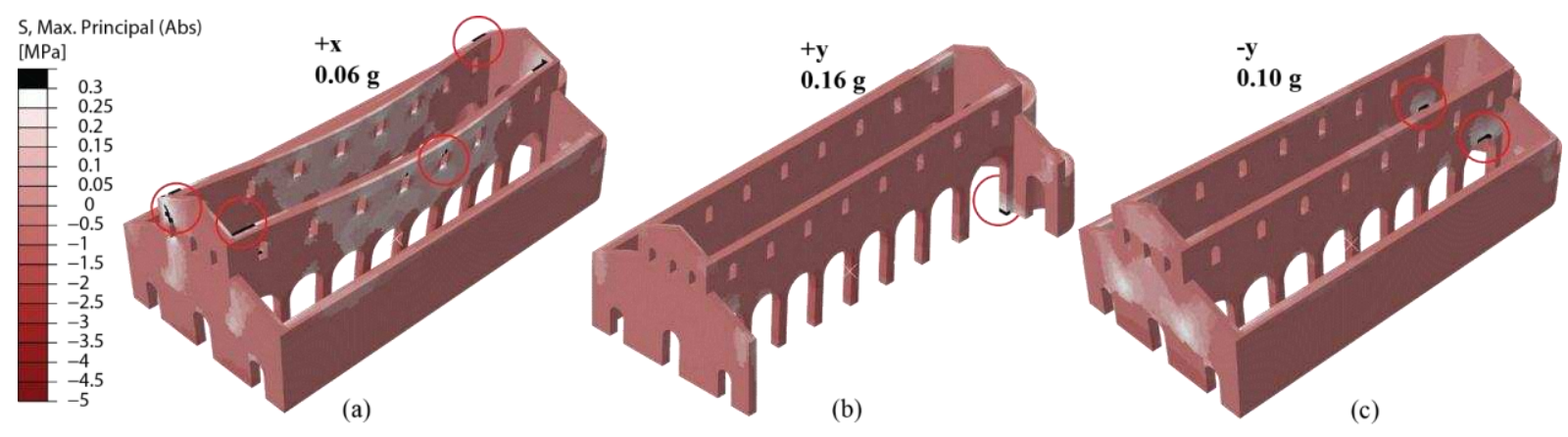

Figure 8: Results of the FEM Model for [BN] church: stress pattern at the failure points for $+x(a),+y(b)$ and $-y$ (c) directions

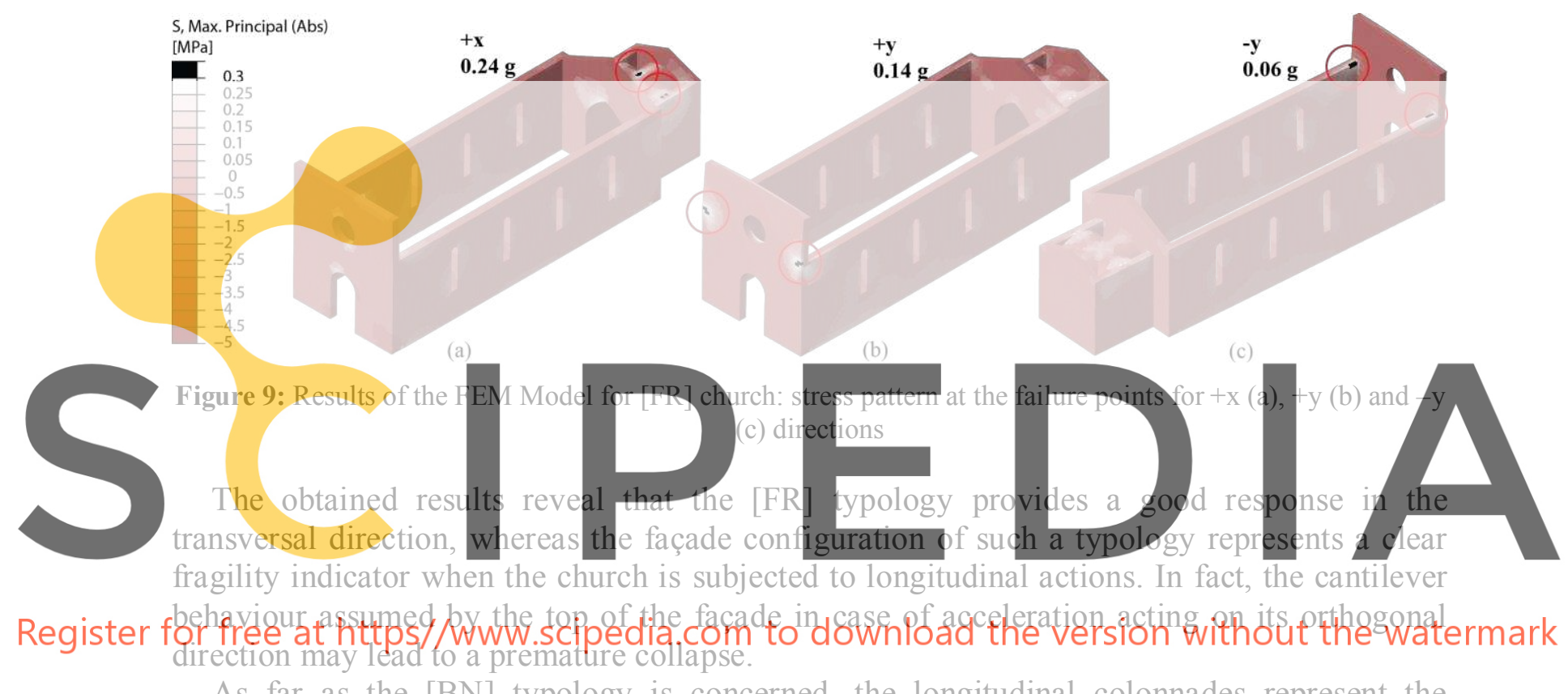

As far as the [BN] typology is concerned, the longitudinal colonnades represent the weakest elements of this three-nave layout. In fact, in case of transversal actions, they may exhibit a response similar to a double fixed beam with a uniformly distributed vertical loads, with stress concentrations in the extremities and in the mid-span. On the contrary, the longitudinal response is highly affected by the presence of the apses, where there is a concentration of the mass and consequently of the internal forces.

\subsection{Comparison with the observed damage}

In order to corroborate the evidences obtained by the above numerical analyses, a comparison with the damage scenario induced by the last seismic events has been carried out. To this purpose, two examples of the damage undergone by Benedictine churches, namely the S. Pietro ad Oratorium church in Capestrano (Aq) and the S. Giustino church in Paganica (Aq), which experienced the L'Aquila 2009 seismic event, are provided in Figure 10.

In both these cases, the seismic damage was mostly concentred in the longitudinal colonnade, confirming the results arisen from the numerical analyses. In particular, in the church of Capestrano a diffused damage in the piers was surveyed, such as to lead the 


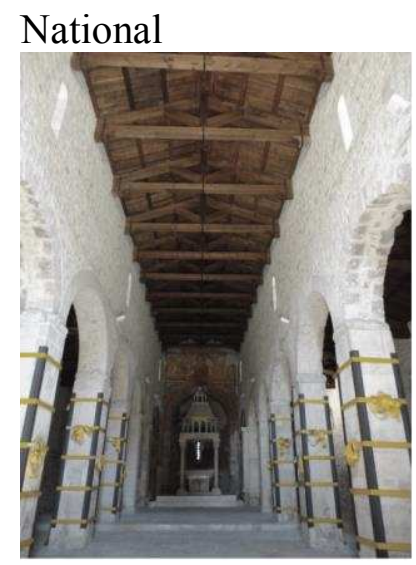

(a)

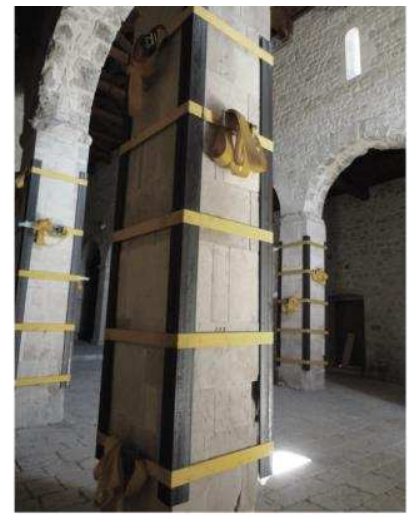

(b)

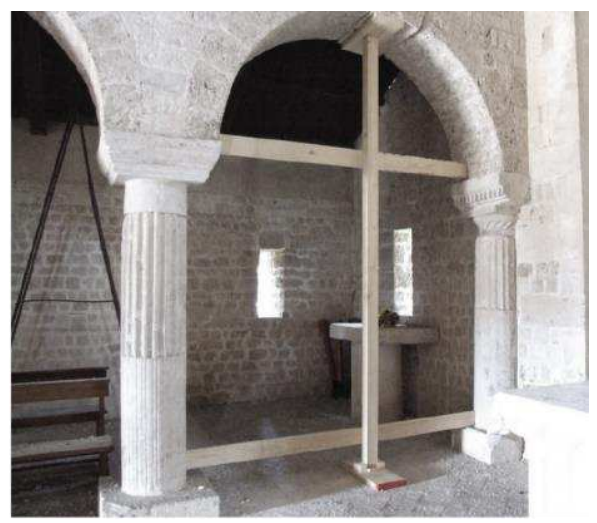

(c)

Figure 10: Seismic damage observed in the colonnades of the churches of $(a, b) S$ Pietro ad Oratorium in Capestrano (Aq) and (c) S. Giustino in Paganica (Aq).

Fire Brigades to operate a diffused provisional intervention in order to avoid a possible collapse (Figure 10a, 10b). Moreover, it is interesting to note in Figure 10c that the revealed damage exactly corresponded to the one predicted by the numerical analysis in the negative and positive y direction: a failure of the arch in proximity of the apse with a collapse mechanism involving also the piers was exhibited, although in this example lateral apses are missing.

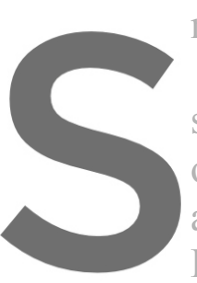

As far as the Francisca seismic behaviour of su of the S. Francesco chu
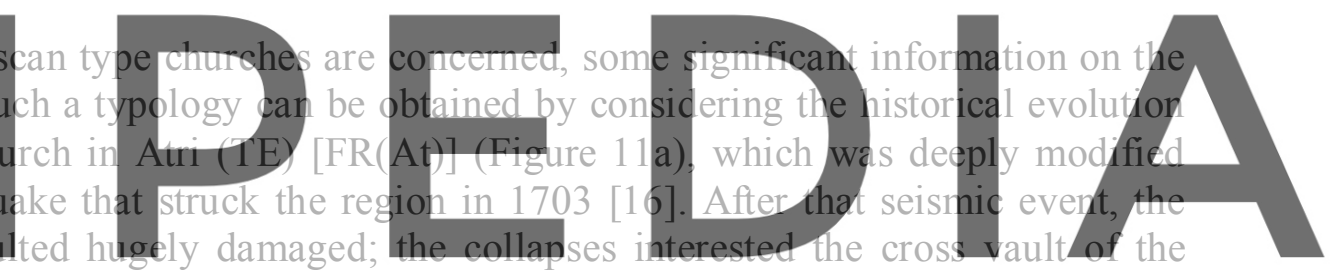

after the strong earthqu

apse, the timber roofing system, the bell tower and the façade, which in particular revealed the

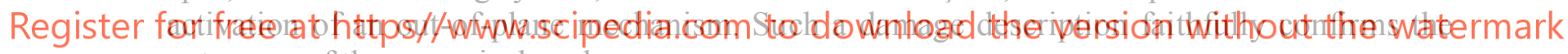
outcomes of the numerical analyses.

Moreover, some evidences of the seismic behaviour of such a typology can be found also considering the churches of S. Francesco in Amatrice (RI) and Norcia (PG), which were both dramatically damaged after the swarm occurred in the Central Italy in 2016-17. Despite both churches exhibited an almost total collapse due to the strong earthquake occurred on the 30th October 2016 (epicentre in Norcia), they resulted seriously damaged also after the first seismic event of August 2016, as shown in Fig. 11b and 11c. Therefore, as predicted by the numerical investigation, the flat termination of the façade represents a significant vulnerability indicator in the Franciscan type.

It is worth noting that, since many churches can reveal similar common geometrical dimensions and constructional features, although they are related to few analysed cases, the above outcomes can have a larger impact and could be extended to the whole category of the examined churches. 


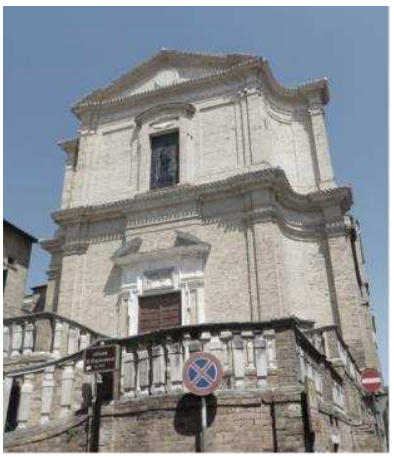

(a)

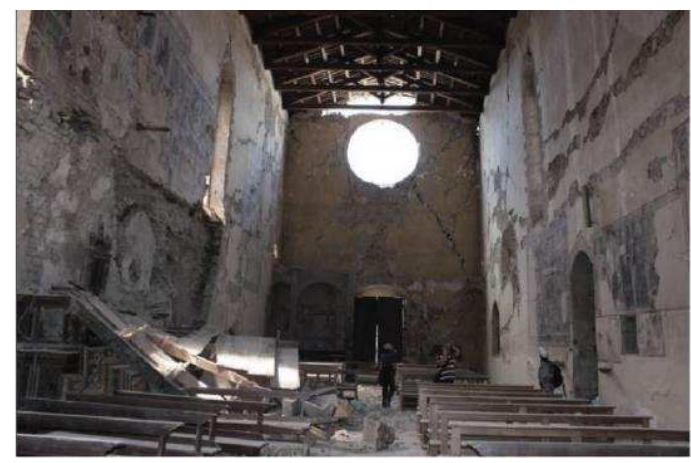

(b)

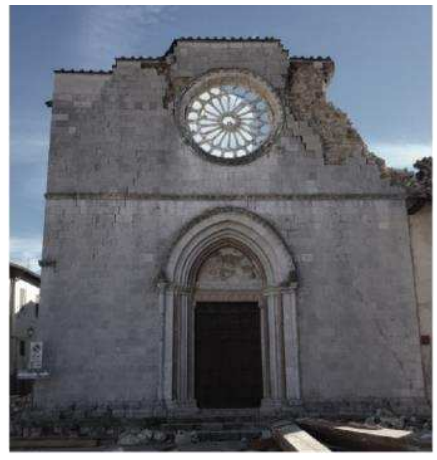

(c)

Figure 11: (a) S. Francesco church in Atri (TE) and significant seismic damage after the first seismic event of the Central-Italy 2016-17 earthquake: S. Francesco churches in (b) Amatrice and (c) Norcia.

\section{CONCLUSIONS}

The present study deals with the seismic vulnerability assessment of monumental buildings. Simplified numerical analyses based on a preventive in-depth historical investigation of medieval Benedictine and Franciscan churches present in Abruzzi have been carried out.

Based on a suitable typological characterization, simplified numerical analyses have been implemented on two churches representative of the investigated typologies. The obtained outcomes showed a good correspondence in terms of collapse mechanisms with the real damage observed in examples of churches that experienced the L'Aquila (2009) and the Central Italy (2016-17) earthquakes.

In the whole, the obtained results demonstrate the reliability of the adopted integrated approach, which appears to be useful to perform large-scale studies and to provide suitable preventive strategies for the protection of the architectural assets in the most earthquake-prone areas.

\section{REFERENCES}

[1] Lagomarsino, S., Podestà, S. Seismic Vulnerability of Ancient Churches: II. Statistical Analysis of Surveyed Data and Methods for Risk Analysis. Earthquake Spectra (2004) 20(2):395-412.

[2] D'Ayala, D. Force and displacement-based vulnerability assessment for traditional buildings. Bulletin of Earthquake Engineering (2005) 3(3):235-265.

[3] De Matteis, G, Brando, G, Corlito, V. Predictive model for seismic vulnerability assessment of churches based on the 2009 L'Aquila earthquake. Bulletin of Earthquake Engineering (2019) 17(9):4909-4936.

[4] De Matteis, G, Zizi, M. Seismic Damage Prediction of Masonry Churches by a PGABased Approach. International Journal of Architectural Heritage (2019) 13 (7):11651179.

[5] Lourenco, P., Roque, J. Simplified indexes for the seismic vulnerability of ancient masonry buildings. Construction and Building Materials (2006) 20:200-208.

[6] Palazzi, N. C., Rovero, L., Llera, J., Sandoval, C. Preliminary Assessment on Seismic Vulnerability of Masonry Churches in Central Chile. International Journal of 
Architectural Heritage (2019). doi:10.1080/15583058.2019.1570388.

[7] Bartolini, S. L. Delle tipologie religiose nell'architettura abruzzese fra 11. e 19. secolo, Pescara: Tipolitografia SIGRAF. (2015). (In Italian).

[8] Gavini I. C. Storia dell'architettura in Abruzzo. Milano; Roma: Casa editrice d'arte Bestetti e Tumminelli. (In Italian).

[9] Di Nucci, A. L'arte di costruire in Abruzzo. Tecniche murarie nel territorio della diocesi di Valva e Sulmona Gange. (2011) (In Italian).

[10] Mancini, R. Le pietre aquilane: processi di approvvigionamento della pietra e sue forme di lavorazione nell'architettura storica. Roma: G.B.E. (2012) (In Italian).

[11] Lourenço, P. B. Computations on historic masonry structures. Progress in Structural Engineering and Materials (2002) 4:301-319.

[12] Brando, G., Criber, E. and De Matteis, G. The effects of L'aquila earthquake on the St. Gemma church in Goriano Sicoli: part II-fem analysis. Bulletin of Earthquake Engineering 13:3733-3748 (2015).

[13] Kujawa, M., Lubowiecka, I. and Szymczak, C. Finite element modelling of a historic church structure in the context of a masonry damage analysis. Engineering Failure Analysis (2020) doi: 10.1016/j.engfailanal.2019.104233.

[14] Lourenço, P.B., Rots, J. and Blaauwendraad, J. Two approaches for the analysis of masonry structures: Micro and macro-modeling. HERON (1995), 40(4):313-340.

[15] De Matteis, G. and Mazzolani, F.M. The Fossanova church: seismic vulnerability assessment by numerical and physical testing. International Journal of Architectural Heritage (2010) 4(3):222-245.

[16] Bartolini Salimbeni, L. Architettura francescana in Abruzzo dal XIII al XVIII secolo. Edigrafica. (1993) (In Italian). 